\title{
NASTAVNIK KAO FAKTOR POBOLJŠANJA EFEKATA NASTAVE FIZIČKOG VASPITANJA UČENIKA MLAĐEG ŠKOLSKOG UZRASTA
}

\section{THE TEACHER AS A FACTOR OF IMPROVING THE EFFECTS OF PHYSICAL EDUCATION CLASSES AMONG YOUNGER SCHOOL AGE CHILDREN}

\section{SAŽETAK}

Cilj ovog istraživanja je prikazati efekte eksperimentalnog tretmana $u$ nastavi fizičkog vaspitanja kod djece uzrasta 10-11 godina. Eksperimentalni tretman je trajao $u$ periodu 01.03.2010. do 01.03.2011. godine u 16 osnovnih škola Republike Srpske/BiH, koji je uključivao volontiranje 20 diplomiranih profesora fizičkog vaspitanja bez radnog iskustva u četvrtim i petim razredima osnovnih škola, koji su provodili nastavu fizičkog vaspitanja umjesto nastavnika razredne nastave, odnosno učitelja, koji u skladu sa zakonskim odredbama provode nastavu u navedenom uzrastu. Tretman je uključivao 1558 učenika $i$ učenica iz gradskih $i$ prigradskih sredina, od toga 1213 ispitanika je bilo $u$ eksperimentalnoj, a 345 ispitanika u kontrolnoj grupi.

Svi učenici su testirani baterijom "Eurofit" testova, odnosno analizirano je sedam varijabli iz oblasti motoričkih sposobnosti. Tretman je odobren od strane Ministarstva porodice, omladine $i$ sporta $i$ Ministarstva prosvjete i kulture Vlade Republike Srpske, a realizovan je u skladu sa Nastavnim planom i programom u saradnji sa ova dva ministarstva, Fakultetom za fizičko vaspitanje $i$ sport Univerziteta $u$ Banjoj Luci i Republičkim pedagoškim zavodom.

Nakon izvršenog inicijalnog i finalnog mjerenja eksperimentalne i kontrolne grupe učenika, došlo se do zaključka da su učenici eksperimentalne grupe postigli statistički značajno bolje rezultate u testovima motoričkih sposobnosti. Budući da je eksperimentalni tretman trajao godinu dana, i da su svi ispitanici testirani istim metodama $u$ istim uslovima, a uvidom u poređene rezultate finalnog mjerenja, može se reći da je rad diplomiranih profesora fizičkog vaspitanja u nastavi fizičkog vaspitanja mlađeg školskog uzrasta pozitivno uticao na razvijanje testiranih motoričkih sposobnosti učenika.

Ključne riječi: nastavnik, nastava fizičkog vaspitanja, mlađi školski uzrast

Moconja, G., Dobraš, R., Tadić, G., Kukrić, A., Petrović, B.,\& Stojanović, D. (2018). Nastavnik kao faktor poboljšanja efekata nastave fizičkog vaspitanja učenika mlađeg školskog uzrasta. Sportlogia, 14 (1), 102-110. doi:10.5550/sgia.181401.se.mdt 


\section{UVOD}

Učenici mlađeg školskog uzrasta su konstantno izloženi velikim stresovima, počevši od toga što su se bezbrižno igrali, neprestano kretali i bili bez kontinuiranih obaveza do polaska u školu. Promjena načina života, koja se, prije svega, odnosi na dugotrajno sjedenje i nošenje školskih torbi, koje su često neadekvatne i preteške za predmetni uzrast, odlična su podloga za stvaranje tjelesnog disbalansa, te pojavu blažih i/ili težih oblika tjelesnih deformiteta.Upravo zato, neophodno je da nastavu fizičkog vaspitanja za učenike mlađeg školskog uzrasta prilagodimo njihovim potrebama, te nadoknadimo bar dio njihove potrebe za kretanjem. Adekvatno i stručno vođena nastava fizičkog vaspitanja ima svakako pozitivno dejstvo na organizam i tjelesni status učenika, ali isto tako, nestručna nastava može imati itekako negativno dejstvo na njihov organizam, ali i na motivaciju za bavljenje fizičkim aktivnostima u budućnosti.

Nastavnim planom i programom za nastavu osnovnog obrazovanja u Republici Srpskoj, predviđen je fond od tri časa fizičkog vaspitanja sedmično za učenike mlađeg školskog uzrasta, odnosno od drugog do četvrtog razreda osnovnih škola (Ministartsvo prosvjete i kulture, 2006). Činjenica da je ovo školski predmet sa najvećim fondom časova (odmah poslije maternjeg jezika i matematike), jasno govori o važnosti ovog školskog predmeta za populaciju mlađeg školskog uzrasta. Zadaci fizičkog vaspitanja učenika ogledaju se u zadovoljavanju potrebe učenika za kretanjem, očuvanjem i učvršćivanjem zdravlja i higijenskih navika, razvijanju motoričkih sposobnosti i psihomotornih osobina, naročito fleksibilnosti, snage, brzine, spretnosti, navikavanje organizma na teža i složenija kretanja, savladavanje i ovladavanje osnovnom tehnikom predviđenih sportskih grana, razvijanje pozitivnih moralno-voljnih osobina, osposobljavanje učenika za praktičnu primjenu savladanih sadržaja u svakodnevnom životu, te razvijanje radnih navika (Hadžikadunić i Mađarević, 2004). Kada se radi o broju sedmičnih časova fizičke aktivnosti, odnosno, potrebnoj sedmičnoj ferkvenciji fizičkog angažovanja učenika, najveći broj autora, poput Findaka (1989), preporučuje minimalno 30 do 60 minuta bavljenja fizičkim aktivnostima dnevno, kako bi se obezbijedio pravilan razvoj djeteta (Strong et al., 2005; Pate et al., 2006). Motoričkim sposobnostima nazivaju se one sposobnosti čovjeka koje učestvuju u rješavanju motornih zadataka i uslovljavaju uspješno kretanje, bez obzira da li su te sposobnosti stečene treningom ili ne (Malacko, 1991). Tokom rasta i razvoja, djeca prolaze kroz senzibilne faze za razvoj motorike, odnosno, periode kada je najpogodnije sistematskim vježbanjem uticati na razvoj određenih sposobnosti. Senzibilne faze su periodi kada sistemi odgovorni za određenu sposobnost prolaze kroz najveće promjene i smatraju se najpogodnijim za primjenu treninga za razvijanje tih sposobnosti. Imajući u vidu upravo ovu činjenicu, potrebno je posvetiti mnogo veću pažnju stručnijoj nastavi fizičkog vaspitanja učenika mlađeg školskog uzrasta, kao i poštivanju propisanog fonda časova za učenike ovog uzrasta.

Nastavnici razredne nastave u osnovnim školama Republike Srpske, koji su u toku svog školovanja pohađali obavezan predmet Metodika fizičkog vaspitanja, u trajanju od dva semestra, provode nastavu fizičkog vaspitanja učenika predmetnog uzrasta. Međutim, prema anketi koja je sprovedena za potrebe izrade Strategije razvoja sporta u Republici Srpskoj za period 2008-2012. godine, Ministarstvo porodice, omladine i sporta (2008) je objavilo da od ukupno 377 ispitanih učenika, samo je 3,9\% ispitanika odgovorilo da ima nastavu fizičkog vaspitanja tri puta sedmično, što je daleko od svakodnevne fizičke aktivnosti, koju autori preporučuju. Volonteri koji su provodili eksperimentalni tretman su iz reda diplomiranih profesora fizičkog vaspitanja i sporta, a imali su zadatak prije svega, provoditi nastavu fizičkog vaspitanja predmetnog uzrasta

Moconja, G., Dobraš, R., Tadić, G., Kukrić, A., Petrović, B.,\& Stojanović, D. (2018). Nastavnik kao faktor poboljšanja efekata nastave fizičkog vaspitanja učenika mlađeg školskog uzrasta. Sportlogia, 14 (1), 102-110. doi:10.5550/sgia.181401.se.mdt

Stranica 103. 
prema Nastavnom planu i programu, kao i u propisanom fondu časova. Profesori fizičkog vaspitanja su u pri realizaciji eksperimentalnog tretmana provodili zadatke u skladu sa didaktičkim principima (princip svjesnosti, zdravstveno-vaspitne usmjerenosti, praktične primjenjivosti, očiglednosti, individualizacije, planskog opterećenja, zabave i razonode i dr), te su dostavljali izvještaj o realizaciji tretmana i nastave uopšte kako bi se vršila kontrola toka eksperimentalnog tretmana. Isti su motivisano i odgovorno pristupili realizaciji tretmana, imajući u vidu da su svjesni važnosti praćenja razvoja motoričkih sposobnosti učenika u okviru nastave fizičkog vaspitanja. Posljednjih godina, autori iz Sjedinjenih Američkih Država posebno naglašavaju pitanja vezana za svrsishodnost praćenja fizičkog razvoja djece i omladine u okviru nastave fizičkog vaspitanja (Keating \& Silverman, 2004; Harris \& Cale, 2006; Mahar \& Rowe, 2008; Morrow \& Ede, 2009). Naime, ovi autori potvrđuju da se krajem `90-tih godina prošlog vijeka pojavljuje novi koncept u praćenju motoričkih struktura koji govori o povezanosti motoričkih sposobnosti i zdravlja, što se razlikuje od dotadašnjih koncepata i shvatanja o mjerenjima i praćenju vrijednosti motoričkih dimenzija djece i omladine.

Cilj ovog istraživanja je utvrditi u kojoj mjeri drugačiji pristup nastavi fizičkog vaspitanja učenika mlađeg školskog uzrasta, odnosno izvođenje nastave fizičkog vaspitanja od strane profesora fizičkog vaspitanja (umjesto nastavnika razredne nastave), utiče na motoričke sposobnosti predmetnog uzrasta.

\section{METODE}

Svi ispitanici su učenici/učenice četvrtog i petog razreda osnovnih škola, odnosno uzrasta 10-11 godina, koji redovno pohađaju nastavu fizičkog vaspitanja i nemaju zdravstvene prepreke za pohađanje nastave. Uzorak je slučajan hotimičan i sastoji se od ukupno 1558 ispitanika (790 učenika i 768 učenica). Eksperimentalna grupa se sastoji od ukupno 1213 ispitanika (634 učenika i 579 učenica). Kontrolnu grupu čini ukupno 345 ispitanika (156 učenika i 189 učenica).

Svi učenici su testirani baterijom "EUROFIT" testova koji su propisani od strane Komiteta za razvoj sporta Savjeta Evrope. Baterija "EUROFIT" testova (Eurofit, 1993) je set od devet jednostavno provodivih testova koji se odnose na fleksibilnost, snagu, izdržljivost i silu. Zbog nepostojanja rekvizita i nedovoljne opremljenosti školskih sportskih sala za izvođenje nastave fizičkog vaspitanja, nije bilo moguće izvođenje dva testa iz standardne baterije testova.

Korišćeni su sljedeći testovi (Hadžikadunić i sar., 2000):

- Flamingo balans test (FLB) - opšta ravnoteža

- Taping rukom (PLT) - brzina alternativnih pokreta

- Pretklon u sjedu (SAR) - gipkost u zglobu kuka

- Skok u dalj iz mjesta (SBJ) - eksplozivna snaga mišića nogu

- Ležanje-sijed (SUP) - repetitivna snaga mišića trbuha i mišića pregibača u zglobu kuka

- Izdržaj u zgibu (BAH) - statička sila mišića ruku i ramenog pojasa

- Čunasto trčanje $10 \times 5$ (SHR) - agilnost

Podaci prikupljeni tokom istraživanja su obrađeni postupcima deskriptivne i komparativne statistike ( $\mathrm{T}$ - test za zavisne uzorke i T- test za nezavisne uzorke) pomoću statističkog paketa IBM SPSS Statistics.

Moconja, G., Dobraš, R., Tadić, G., Kukrić, A., Petrović, B.,\& Stojanović, D. (2018). Nastavnik kao faktor poboljšanja efekata nastave fizičkog vaspitanja učenika mlađeg školskog uzrasta. Sportlogia, 14 (1), 102-110. doi:10.5550/sgia.181401.se.mdt

Stranica 104. 


\section{REZULTATI}

Analizom deskriptivne statistike obe grupe utvrđeno je da vrijednosti aritmetičkih sredina svih varijabli upućuju na bolji rezultat u finalnom mjerenju. Koeficijenti varijacije, kao reprezenti homogenosti grupe ukazuju da, za većinu varijabli, posmatrani uzorak ne predstavlja homogen skup. Za ovo istraživanje je od posebnog interesa posmatranje opserviranih grupa ponaosob, kao i njihovo poređenje, pa se pristupilo pojedinačnoj analizi grupa. Pripadnici, kako kontrolne, tako i eksperimentalne grupe ponaosob, predstavljaju pojedinačne homogene skupove po rezultatima testova koji su takvi da ih svi učenici mogu, manje ili više, uspješno izvršiti. Problem homogenosti se pojavljuje tamo gdje su zadaci takvi da ih veliki broj učenika ne može izvršiti, tako da ti učenici čine poseban subuzorak unutar grupe kojoj pripadaju. Navedeno se posebno odnosi na testove BAH, SUP i FLB.

T test za zavisne uzorke kod kontrolne grupe (Tabela 1) je pokazao da su ispitanici kontrolne grupe postigli bolje rezultate na finalnom nego na inicijalnom mjerenju. Za testove FLB i SAR ta razlika nije statistički značajna, dok je za ostale testove uočena značajnost na nivou 0.05 (SBJ, SUP, BAH) i 0.01 (SHR i PLT). T test za zavisne uzorke kod eksperimentalne grupe (Tabela 2) je pokazao da je eksperimantalna grupa u svim mjerenim varijablama ostvarila bolje rezultate u finalnom mjerenju u odnosu na postignute rezultate na inicijalnom mjerenju, a to nam govori i značajnost tih razlika, koja je na nivou 0.01. Značajnost razlike za varijablu SAR je na nivou 0.05 .

Tabela 1. Razlike između inicijalnog i finalnog mjerenja kontrolne grupe

\begin{tabular}{lcccc}
\hline Varijabla & INI & FIN & T & $\mathrm{p}$ \\
\hline FLB & 1.73 & 1.82 & -1.708 & .089 \\
PLT & 16.46 & 15.71 & 3.944 & $\mathbf{. 0 0 0 *}$ \\
SAR & 18.12 & 17.93 & .605 & .546 \\
SBJ & 134.40 & 131.22 & -2.445 & $\mathbf{. 0 1 5} *$ \\
SUP & 17.10 & 17.95 & -2.510 & $\mathbf{. 0 1 3}$ \\
BAH & 13.61 & 15.17 & -2.317 & $\mathbf{. 0 2 1}^{*}$ \\
SHR & 26.41 & 25.88 & 2.864 & $\mathbf{. 0 0 4}^{*}$ \\
\hline
\end{tabular}

Legenda: INI - aritmetička sredina inicijalnog mjerenja; FIN - aritmetička sredina finalnog mjerenja; $\mathrm{T}$ - $\mathrm{t}$ test za zavisne uzorke; $\mathrm{p}$ - koeficijent značajnosti razlika;

* - statistički značajne razlike.

Tabela 2. Razlike između inicijalnog i finalnog mjerenja eksperimentalne grupe

\begin{tabular}{lcccc}
\hline Varijabla & INI & FIN & T & $\mathrm{p}$ \\
\hline FLB & 1.67 & 2.22 & -47.375 & $\mathbf{. 0 0 0} *$ \\
PLT & 16.94 & 14.56 & 11.738 & $\mathbf{. 0 0 0}^{*}$ \\
SAR & 17.97 & 18.48 & -2.142 & $\mathbf{. 0 3 2}^{*}$ \\
SBJ & 134.16 & 140.56 & -9.350 & $\mathbf{. 0 0 0}^{*}$ \\
SUP & 17.05 & 19.97 & -19.729 & $\mathbf{. 0 0 0}^{*}$ \\
BAH & 13.24 & 18.19 & -11.903 & $\mathbf{. 0 0 0}^{*}$ \\
SHR & 26.92 & 24.78 & 11.172 & $\mathbf{. 0 0 0}$ \\
\hline
\end{tabular}

Legenda: INI - aritmetička sredina inicijalnog mjerenja; FIN - aritmetička sredina finalnog mjerenja; $\mathrm{T}$ - $\mathrm{t}$ test za zavisne uzorke; $\mathrm{p}$ - koeficijent značajnosti razlika; * - statistički značajne razlike.

Moconja, G., Dobraš, R., Tadić, G., Kukrić, A., Petrović, B.,\& Stojanović, D. (2018). Nastavnik kao faktor poboljšanja efekata nastave fizičkog vaspitanja učenika mlađeg školskog uzrasta. Sportlogia, 14 (1), 102-110. doi:10.5550/sgia.181401.se.mdt

Stranica 105. 
Naravno da je za ovo istraživanje od izuzetnog značaja za postojanje ili nepostojanje razlika između kontrolne i eksperimentalne grupe. Da bi se došlo do ovih podataka korištena je statistička procedura T-test za nezavisne uzorke. T test za nezavisne uzorke kompletnog uzorka (Tabela 3) je pokazao da ne postoji statistički značajna razlika u postignutim rezultatima na inicijalnom mjerenju. Ovaj podatak je od izuzetnog značaja za dalji tok istraživanja, imajući u vidu koliko je važna ujednačenost grupa koje namjeravamo podvrgnuti nekom eksperimentalnom postupku. Za predmetni uzorak je to od posebnog značaja, znajući da uzorak ne možemo dodatno ujednačavati, jer bi u tom slučaju trebalo premještati učenike iz odjeljenja, što je u praksi neizvodljivo. Nepostojanje značajnih razlika testiranih grupa na inicijalnom mjerenju (Tabela 3) je očekivano, imajući u vidu da su uzorkom obuhvaćeni učenici istog uzrasta koji su tretirani istim načinom izvođenja nastave fizičkog vaspitanja.

Tabela 3. Razlike između grupa na inicijalnom mjerenju

\begin{tabular}{lcccc}
\hline Varijable & Mean K & Mean E & $\mathrm{t}$ & $\mathrm{p}$ \\
\hline FLB & 1.73 & 1.67 & -1.339 & 0.245 \\
PLT & 16.46 & 16.94 & 1.540 & 0.124 \\
SAR & 18.12 & 17.97 & -0.298 & 0.725 \\
SBJ & 134.40 & 134.16 & -0.151 & 0.880 \\
SUP & 17.10 & 17.05 & -0.137 & 0.891 \\
BAH & 13.61 & 13.24 & -0.440 & 0.660 \\
SHR & 26.41 & 26.92 & 1.341 & 0.180 \\
\hline
\end{tabular}

Legenda: Mean K - aritmetička sredina kontrolne grupe; Mean E - aritmetička sredina eksperimentalne grupe; $\mathrm{t}$ - $\mathrm{t}$ test za nezavisne uzorke; $\mathrm{p}$ - koeficijent značajnosti razlika; * - statistički značajne razlike.

Tokom eksperimentalnog perioda, koji je trajao godinu dana, sa učenicima koji pripadaju kontrolnoj grupi izvođena je nastava fizičkog vaspitanja na uobičajen način koju je izvodio nastavnik razredne nastave. Sa učenicima pripadnicima kontrolne grupe, su radili profesori fizičkog vaspitanja umjesto nastavnika razredne nastave. Nakon eksperimentalnog perioda, izvršeno je finalno mjerenje sa ciljem da se poređenjem rezultata eksperimentalne i kontrolne grupe utvrdi postojanje eventualnih razlika (Tabela 4).

Tabela 4. Razlike između grupa na finalnom mjerenju

\begin{tabular}{lcccc}
\hline Varijable & Mean $\mathrm{K}$ & Mean E & $\mathrm{t}$ & $\mathrm{p}$ \\
\hline FLB & 1.82 & 2.22 & 11.072 & $\mathbf{0 . 0 0 0} *$ \\
PLT & 15.71 & 14.56 & -3.420 & $\mathbf{0 . 0 0 0 *}$ \\
SAR & 17.93 & 18.48 & 1.028 & 0.172 \\
SBJ & 131.22 & 140.56 & 5.190 & $\mathbf{0 . 0 0 0}^{*}$ \\
SUP & 17.95 & 19.97 & 5.955 & $\mathbf{0 . 0 0 0}^{*}$ \\
BAH & 15.17 & 18.19 & 2.658 & $\mathbf{0 . 0 0 2} *$ \\
SHR & 25.88 & 24.78 & -3.148 & $\mathbf{0 . 0 0 0 *}$ \\
\hline
\end{tabular}

Legenda: Mean K - aritmetička sredina kontrolne grupe; Mean E - aritmetička sredina eksperimentalne grupe; $\mathrm{t}$ - $\mathrm{t}$ test za nezavisne uzorke; $\mathrm{p}$ - koeficijent značajnosti razlika; * - statistički značajne razlike.

Moconja, G., Dobraš, R., Tadić, G., Kukrić, A., Petrović, B.,\& Stojanović, D. (2018). Nastavnik kao faktor poboljšanja efekata nastave fizičkog vaspitanja učenika mlađeg školskog uzrasta. Sportlogia, 14 (1), 102-110. doi:10.5550/sgia.181401.se.mdt

Stranica 106. 
U tabeli 4 prezentovani su rezultati $\mathrm{T}$ testa eksperimentalne i kontrolne grupe na finalnom mjerenju. Kao što se vidi iz prikazanog, postoji statistički značajna razlika u svim mjerenim varijablama u korist eksperimentalne grupe, osim u varijabli SAR. Značajnost razlika varijabli FLB, PLT, SBJ, SUP i SHR je na nivou značajnosti 0.01, dok je značajnost varijable BAH na nivou 0.05 .

\section{DISKUSIJA}

Uzevši u obzir da su svi ispitanici u senzitivnom periodu razvijanja motoričkih sposobnosti, bilo je očekivano da će i kontrolna i eksperimentalna grupa u pojedinačnim mjerenjima pri analizi $\mathrm{T}$ testa za zavisne uzorke postići bolje rezultate na finalnom mjerenju $\mathrm{u}$ odnosu na inicijalno. Međutim, ključno za ovo istraživanje jeste postojanje razlika između grupa ispitanika na inicijalnom i finalnom mjerenju, dobijenih T testom za nezavisne uzorke, koji nam govori da postoje statistički značajne razlike između kontrolne i eksperimentalne grupe ispitanika na finalnom mjerenju.

FLB: Postoji statistički značajna razlika između kontrolne i eksperimentalne grupe na nivou značajnosti $0.01(\mathrm{p}=.000)$. Eksperimentalna grupa je postigla bolje rezultate. Na inicijalnom mjerenju razlika između grupa nije bila statistički značajna.

PLT: Između kontrolne i eksperimentalne grupe postoji statistički značajna razlika na nivou značajnosti $0.01(\mathrm{p}=.000)$. Eksperimentalna grupa je postigla bolje rezultate. Na inicijalnom mjerenju razlika nije bila statistički značajna.

SAR: Razlika za posmatranu varijablu nije statistički značajna ( $\mathrm{p}=.172)$, mada je eksperimentalna grupa postigla malo bolji rezultat, koji nije statistički značajan. Treba napomenuti da je prilikom analize rezultata inicijalnog $\mathrm{i}$ finalnog mjerenja unutar grupa utvrđen statistički značajan napredak eksperimentalne grupe na nivou značajnosti 0.05 ( $\mathrm{p}=0.032)$, dok napredak kontrolne grupe nije statistički značajan. Objašnjenje za nepostojanje značajnosti razlike među grupama na finalnom mjerenju za predmetnu varijablu, može se tražiti u činjenici da je kontrolna grupa na inicijalnom mjerenju imala bolje rezultate (iako razlika nije statistički značajna), dok je na finalnom mjerenju bolja bila eksperimentalna grupa.

$S B J$ : Utvrđeno je da se kontrolna i eksperimentalna grupa statistički značajno razlikuju na nivou značajnosti $0.01(\mathrm{p}=.000)$. Eksperimentalna grupa je postigla bolje rezultate. Na inicijalnom mjerenju rezultati su bili ujednačeni.

SUP: Kod posmatrane varijable utvrđeno je da se kontrolna i eksperimentalna grupa statistički značajno razlikuju na nivou značajnosti $0.01(\mathrm{p}=.000)$ u korist eksperimentalne grupe, koja je postigla bolje rezultate. Na inicijalnom mjerenju rezultati su bili ujednačeni.

$B A H$ : Kontrolna i eksperimentalna grupa statistički značajno razlikuju na nivou značajnosti 0.01 $(\mathrm{p}=.002)$ u korist eksperimentalne grupe. Na inicijalnom mjerenju rezultati su bili ujednačeni.

SHR: Između kontrolne i eksperimentalne grupe postoji statistički značajna razlika na nivou značajnosti $0.01(\mathrm{p}=.000)$. Eksperimentalna grupa je postigla bolje rezultate. Na inicijalnom mjerenju rezultati su bili ujednačeni.

Treba svakako naglasiti da se vide pozitivni efekti razvijanja motoričkih sposobnosti kroz redovno provođenje nastvanog plana i programa. Zurc (2009) je proveo istraživanje koje pokazalo je da obavezno fizičko vaspitanje u osnovnim školama u Sloveniji nije dovoljno za dječiju potrebu za redovnom fizičkom aktivnošću, a naš slučaj pokazuje kako redovna nastava ima pozitivne efekte.

Moconja, G., Dobraš, R., Tadić, G., Kukrić, A., Petrović, B.,\& Stojanović, D. (2018). Nastavnik kao faktor poboljšanja efekata nastave fizičkog vaspitanja učenika mlađeg školskog uzrasta. Sportlogia, 14 (1), 102-110. doi:10.5550/sgia.181401.se.mdt

Stranica 107. 


\section{ZAKLJUČAK}

$\mathrm{Na}$ osnovu dobijenih rezultata istraživanja, izvedeni su sljedeći zaključci:

$\mathrm{Na}$ inicijalnom mjerenju u svim mjerenim varijablama nije bilo statistički značajnih razlika između kontrolne i eksperimentalne grupe.

$\mathrm{Na}$ finalnom mjerenju eksperimentalna grupa ispitanika je postigla statistički značajno bolje rezultate u motoričkim testovima osim u varijabli SAR.

$\mathrm{Na}$ osnovu provedenog istraživanja i jednogodišnjeg eksperimentalnog tretmana u okviru kojeg su diplomirani profesori fizičkog vaspitanja provodili nastavu fizičkog vaspitanja umjesto nastavnika razredne nastave, a u skladu sa dobijenim rezultatima istraživanja, zaključuje se da su učenici eksperimentalne grupe za godinu dana eksperimentalnog trentmana postigli statistički značajno bolje rezultate u testovima motoričkih sposobnosti.

Eksperimentalnoj grupi učenika je navedenim tretmanom obezbjeđena stručnija nastava fizičkog vaspitanja što je prouzrokovalo bolje rezultate na testovima motoričkih sposobnosti, u poređenju sa učenicima istog uzrasta koji nisu bili pod uticajem eksperimentalnog tretmana.

Praktični značaj rada može se posmatrati u užem i širem smislu. U užem smislu doprinos se ogleda u značajnom poboljšanju motoričkih sposobnosti i odnosu prema nastavi učenika eksperimentalne grupe. Isto tako, treba napomenuti da je nastava fizičkog vaspitanja, u školama koje su bile obuhvaćene projektom, dobila na značaju, jer je značajno promijenjen odnos prema nastavi (roditelji, školska rukovodstva, nastavnici koji predaju ostale predmete, nastavnici razredne nastave...) U širem smislu, doprinos istraživanja je u samom učešću Vlade Republike Srpske u realizaciji ovog istraživanja i spremnosti da se fizičko vaspitanje mlađeg školskog uzrasta tretira na način koji to, zbog važnosti ovog perioda u razvoju čovjeka, i zaslužuje.

Moconja, G., Dobraš, R., Tadić, G., Kukrić, A., Petrović, B.,\& Stojanović, D. (2018). Nastavnik kao faktor poboljšanja efekata nastave fizičkog vaspitanja učenika mlađeg školskog uzrasta. Sportlogia, 14 (1), 102-110. doi:10.5550/sgia.181401.se.mdt

Stranica 108. 


\section{LITERATURA}

Eurofit (1993). Eurofit Tests of Physical Fitness, $2^{\text {nd }}$ Edition, Strasbourg, FRA.

Findak, V. (1989). Metodika tjelesne i zdravstvene kulture: priručnik za nastavnike razredne nastave. Školska knjiga. Zagreb.

Hadžikadunić, M., Rađo, I., Grozdanić, B., \& Turković, S. (2000). Priručnik za testiranje eurofit baterijom testova. Sarajevo, BiH: Madž.

Hadžikadunić, M., \& Mađarević, M. (2004). Metodika tjelesnog odgoja sa osnovama fiziologije tjelesnog vježbanja. Zenica, BiH. Pedagoški fakultet.

Harris, J., \& Cale, L., (2006). A review of children`s fitness testing. European Physical Education Review, 12(2), 201-225. https://doi.org/10.1177/1356336X06065359

Keating, X. D., \& Silverman, S. (2004). Teacher`s Use of Fitness Tests in School-Based Physical Education Programs. Measurement in Physical Education and Exercise Science, 8(3), 145165. https://doi.org/10.1207/s15327841mpee0803_2

Mahar, M. T., \& Rowe, D.A. (2008). Practical Guidelines for Valid and Reliable Youth Fitness Testing. Measurement in Physical Education and Exercise Science, 12, 126-145. https://doi.org/10.1080/10913670802216106

Malacko, J. (1991), Osnove sportskog treninga, Kibernetički pristup. Novi Sad, RS: Biblioteka Matice srpske.

Ministarstvo porodice, omladine i sporta. (2008). Strategija razvoja sporta u Republici Srpskoj za period 2008-2012. godine [Zvanični podaci].

Ministarstvo prosvjete i kulture. (2006). Nastavni plan i program za osnovnu školu, Prva trijada. Banja Luka, BiH: Autor.

Morrow, J. R., \& Ede, A. (2009). Research Quarterly for exercise and Sport Lecture Statewide Physical Fitness Testing: A BIG Waist or a BIG Waste? Research Quarterly for exercise and Sport, 80, 696-701.

https://doi.org/10.1080/02701367.2009.10599610

PMid:20025110

Pate, R. R., Davis, M. G., Robinson, T. N., Stone, E. J., McKenzie, T. L., \& Young, C.J. (2006). Promoting Physical Activity in Children and Youth - A Leadership Role for Schools. Circulation. Journal of American Heart Association, 114, 1214-1224. PMid:16908770

Strong, W. B., Malina, R. M., Blimkie, C. J., Daniels, S. R., Dishman, R.K, Gutin, B., Hergenroeder, A. C., Must, A., Nixon, P. A., Pivarnik, J. M., Rowland, T., Trost, S., \& Trudeau, F. (2005). Evidence based on physical activity for schoolage youth. Journal of Pediatrics, 164, 732-737. https://doi.org/10.1016/j.jpeds.2005.01.055

PMid:15973308

Zurc, J. (2009). Veza između akademske kompetencije i fizičke aktivnosti mlađih učenika. In Bokan, B. (Eds.), Međunarodna naučna konferencija: Teorijski, metodološki i metodički aspekti fizičkog vaspitanja (pp. 84-88). Beograd, RS: Fakultet sporta i fizičkog vaspitanja.

Moconja, G., Dobraš, R., Tadić, G., Kukrić, A., Petrović, B.,\& Stojanović, D. (2018). Nastavnik kao faktor poboljšanja efekata nastave fizičkog vaspitanja učenika mlađeg školskog uzrasta. Sportlogia, 14 (1), 102-110. doi:10.5550/sgia.181401.se.mdt 


\section{SUMMARY}

The aim of this research was to present the effects of an experimental program including physical education classes among children aged 10-11. The experimental treatment lasted from March 1, 2010 to March 1, 2011, was realized in 16 elementary schools in the Republic of Srpska/B-H, and included the volunteer work of 20 physical education professors with no previous work experience with fourth and fifth grade students, that is, teachers, who in accordance with the law carry out the prescribed work with the aforementioned age group. The program included 1558 male and female students from city and suburb areas, 1213 of whom made up the experimental, and 345 the control group.

All of the participants were tested using the "EUROFIT" battery of tests. Seven variables from the area of motor skills were analyzed. The program was approved by the Ministry of Family, Youth and Sports and the Ministry of Education and Culture of the Republic of Srpska, and was realized in accordance with the national curriculum with the help of these two ministries, the Faculty of Physical Education and Sport of the University of Banja Luka and the Pedagogical Institute.

Following the completion of the initial and final measurements of the experimental and control group, the conclusion was reached that the students from the experimental group achieved statistically significant better results on the tests of motor skills. Considering that the experimental program lasted for one year, and that all the participants were tested using the same methods and under the same conditions, and after comparing the results of the final measurement, we could say that the work of the physical education teachers during physical education classes for younger school age children had a positive effect on the development of the tested motor skills of the students.

Keywords: teacher, physical education classes, younger school age

Primljeno: 25.05.2018.

Odobreno:03.06.2018.

Korespondencija: Gorica Bilak - Moconja,

magistar nauka u oblasti fizičke kulture,

viši stručni saradnik za školski sport u Ministarstvu porodice, omladine i sporta, Republika Srpska, Bosna i Hercegovina, goricabilak@gmail.com

Moconja, G., Dobraš, R., Tadić, G., Kukrić, A., Petrović, B.,\& Stojanović, D. (2018). Nastavnik kao faktor poboljšanja efekata nastave fizičkog vaspitanja učenika mlađeg školskog uzrasta. Sportlogia, 14 (1), 102-110. doi:10.5550/sgia.181401.se.mdt

Stranica 110. 